\title{
Use of foliar fertilizers on soybeans in the Republic of Tatarstan
}

\author{
Valeria Kolesar*, Gulsia Sharipova, Diana Safina, and Radik Safin \\ Department of General Farming, Plant Protection and Breeding, Kazan State Agrarian University, 420015 K.Marx str., Kazan, Russia
}

\begin{abstract}
In 2018, studies were conducted to assess the impact of foliar feeding with complex fertilizers on the yield and grain quality of two soybean varieties. Weather conditions throughout the year were noted periodically dry in May, June and August. Metallocene ${ }^{\circledR}$ fertilizers with different mineral nutrition elements were used for soybean spraying. The fertilizers were used for spraying in the soybean beginning bloom stage. Epy control served as a variant without foliar feeding. It was found that the variety Annushka in the conditions of 2018 was more productive than the variety Milyaushaa. The difference between the varieties in the control was $0.3 \mathrm{t} / \mathrm{ha}$. Low yield in the control sample was associated with the negative effect of drought on the existing root system and the nudeles on it. Spraying Annushka crops by Metallocene ${ }^{\circledR}$ A with copper has high positive effect on the yield. The yield increase from this fertilizer was $0.72 \mathrm{t} / \mathrm{ha}$. In case with Milyaushaa, the best indicators were achieved by Metallocene ${ }^{\circledR}$ D spraying with manganese. In case the yield increased by $0.79 \mathrm{t} / \mathrm{ha}$. The use of foliar feeding had positive effect on soybean seed size. The maximum 1000 seed weight Annushka was for Metallocene ${ }^{\circledR}$ A with copper. For Milyaushaa the largest seeds were when using Metallocene $\AA$ D with manganese. Foliar feeding by Metallocene ${ }^{\circledR}$ D with manganese had positive effect on phosphorus accumulation in seeds.
\end{abstract}

\section{Introduction}

Soybean is one of the most important legumes with significant distribution in various regions of the world [1-3]. The most valuable features of this culture include high content of protein in the grain, which is essential both for food industry and in fodder production [4-6]. One of the key problems in world soybean production is the negative impact of global climate change on crop productivity, which requires measures to increase plant stress resistance [7].

Currently in Russia there is a stable growth trend of both sown areas and volumes of soybean production [8]. The possibility of obtaining sustainable soybean crops in Tatarstan is reflected in many studies [9, 10], but, still this culture in the republic is not widely spread and is way below peas. There are both natural and agricultural reasons of limited soybean cultivation in the Republic of Tatarstan [11, 12]. The latter include the selection of varieties, as well as the optimization of mineral nutrition of the culture.

At present, there is a large number of both domestic and foreign varieties, which allow forming stable soybean crops in the conditions of the Volga region [13, 14]. However, the selection of soybean varieties, especially in the context of recurrent droughts in the region, remains quite a challenge.

Soybean is one of the crops requiring mineral nutrition, so the optimization of the fertilizer system is essential in the technology of its cultivation $[15,16]$. The use of various micronutrients containing certain microelements or their combination plays a significant role in increasing crop yield $[17,18]$. One method of applying micronutrients to soybean is foliage application, i.e. spraying of plants. The efficiency of this method in agricultural technology of soybean production is quite high $[19,20]$.

However, the application of micronutrients elements requires the consideration of various factors such as the presence of microelements in soil, grade features, as well as forms, period and methods of their application [21], which defines the need for appropriate study. New micronutrients include Metallocene fertilizers containing various microelements in the form of chelates in combination with macroelements.

Besides, they include growth regulators. The creation of complex preparations of microelements and growth regulators for foliage application is one of the main directions to optimize plant mineral nutrition [22]. In addition, modern liquid complex fertilizers with growthstimulating effect can play a significant role in crop management technologies, including soybeans [23].

The purpose of the study was to test the efficiency of foliage application of different micronutrients of Metallocene series on different soybean varieties. The tasks of the study included the assessment of the impact of these techniques on yield and chemical composition of grain in soybean varieties Milyausha and Annushka.

\section{Materials and methods}

The study was carried out in the experimental field of Kazan SAU in 2018. The object of the study included

Corresponding author: Klerochka@gmail.com 
soybean varieties Annushka (Poland) and Milyausha (Russia, Tatarstan).

The following foliage application options were studied: 1. Control - without treatment; 2. Metallocene A (with copper); 3. Metallocene B (with zinc); 4. Metallocene D (with manganese); 5. Metallocene E (with iron).

Metallocene preparations represent liquid fertilizers with microelements in the form of chelates.

Spraying was carried out in budding-early bloom stage. The consumption rate of preparations - $1.0 \mathrm{l} / \mathrm{ha}$. The total plot area $-56 \mathrm{~m}^{2}$, accounting area $-50 \mathrm{~m}^{2}$. Repetition - quadruple. Sowing norm $-0.5 \mathrm{mln}$ v.s./ha. Sowing was carried out with inter-rows of $30 \mathrm{~cm}$. Ammophoska (2 c/ha) was introduced under pre-sowing cultivation. The precursor is winter wheat by complete fallow. Operating fluid flow rate at spraying - $200 \mathrm{l} / \mathrm{ha}$. Seed reproduction - ES1. Prior to sowing the seeds were treated with a special bacterial preparation for inoculation with tuber bacterium - soya Rhizotorfin. The soil of the experimental site is grey forest middle loamy soils, humus content $-3.1 \%$, exchangeable potassium $170 \mathrm{mg} / \mathrm{kg}$, mobile phosphorus - $180.0 \mathrm{mg} / \mathrm{kg}$. Agricultural cultivation technology was according to recommendations for the Republic of Tatarstan [6]. In terms of providing the soil with accessible forms of microelements, then regarding the content of copper, zinc and manganese the soil can be characterized as soil with an average content of these microelements.

Weather conditions of the vegetation period were characterized by occasional dry phenomena in May, June and August, as well as excessive moistening in July.

Biometric values were determined via traditional methods. Grain analysis for macroelements was carried out in a certified laboratory.

Statistical processing of experimental data was carried out according to traditional methods [24] with calculation of the least significant difference and standard deviation. To assess the accuracy of the difference for average values, the standard deviation was determined via the Student's t-test $(\mathrm{P}<0.05)$.

\section{Results and discussion}

Foliage application affected biometric indicators of soybean growth (Table 1).

The effect of additional fertilization on biometric indicators depended on fertilizer composition and variety. Concerning Annushka, all preparations reliably increased the height of plants and the number of grains formed in one bean. The growth of the total number of beans per 1 plant occurred during spraying with preparations containing copper, zinc and iron. The maximum height of plants (stem length) was with the use of the preparation with iron and manganese. The largest number of beans per plant was when sprayed with the preparation with iron. The largest number of grains in a bean were formed using iron preparation.
Table 1. Biometric indicators of soybean growth and development, 2018

\begin{tabular}{|c|c|c|c|}
\hline Option & $\begin{array}{l}\text { Stem } \\
\text { length, } \\
\mathrm{cm}\end{array}$ & $\begin{array}{l}\text { Number of } \\
\text { beans per } 1 \\
\text { plant, pcs. }\end{array}$ & $\begin{array}{l}\text { Number of } \\
\text { grains per } 1 \\
\text { bean, pcs. }\end{array}$ \\
\hline \multicolumn{4}{|c|}{ Annushka } \\
\hline Control & 34.0 & 4.1 & 2.1 \\
\hline $\begin{array}{l}\text { Grade } \\
(\mathrm{Cu})\end{array}$ & 67.3 & 6.5 & 2.5 \\
\hline $\begin{array}{ll}\text { Grade } & \text { B } \\
(\mathrm{Zn}) & \\
\end{array}$ & 62.2 & 5.2 & 2.4 \\
\hline $\begin{array}{ll}\begin{array}{l}\text { Grade } \\
(\mathrm{Mn})\end{array} & \mathrm{D} \\
\end{array}$ & 68.4 & $4.5^{*}$ & 3.0 \\
\hline $\begin{array}{ll}\text { Grade } & \mathrm{E} \\
(\mathrm{Fe}) & \end{array}$ & 69.7 & 5.6 & 2.5 \\
\hline \multicolumn{4}{|l|}{ Milyausha } \\
\hline Control & 37.9 & 3.2 & 2.5 \\
\hline $\begin{array}{l}\text { Grade } \\
(\mathrm{Cu})\end{array}$ & 51.0 & 6.0 & $2.6^{*}$ \\
\hline $\begin{array}{ll}\text { Grade } & \text { B } \\
(\mathrm{Zn}) & \\
\end{array}$ & $44.0 *$ & 4.5 & 2.8 \\
\hline $\begin{array}{l}\text { Grade } \quad \text { D } \\
(\mathrm{Mn})\end{array}$ & 54.6 & 6.2 & $2.5^{*}$ \\
\hline $\begin{array}{ll}\text { Grade } & \mathrm{E} \\
(\mathrm{Fe}) & \end{array}$ & $44.5^{*}$ & $3.0 *$ & 3.3 \\
\hline
\end{tabular}

Note: $*$ - the difference is not reliable in relation to the control for the corresponding class in terms of the standard deviation at $\mathrm{P}=0.05$ (5\% error)

Concerning Milyausha, the growth stimulating effect was noticed for preparations with iron and manganese. The increase in the number of beans and the number of grains was observed only for zinc-containing preparation. The maximum length of plants and the largest number of beans per plant was achieved through fertilization with manganese preparation. The number of grains in a bean was the highest when the crops were treated with iron preparation.

Thus, in both soybean varieties, the growth stimulation (stem length) was observed when foliage application of the manganese preparation was used. The impact of microelements on the number of beans per plant and the number of grains in a bean was different for different soybean varieties.

Table 2 shows the results of soybean seed yield and size. In 2018, Annushka variety was more productive than the Milyausha variety. At the same time, the weight of 1000 grains of Annushka variety was higher than Milyausha variety. When comparing yields it can be noted that in almost all options of the experiment the use of feeding gave a positive result. One of the reasons for this is drought during budding period, as well as weak development of roots and complete absence of tangles on roots due to moisture stress in May. 
Table 2. Yield of various soybean varieties through foliage application of microelements, 2018

\begin{tabular}{|c|c|c|c|c|}
\hline $\begin{array}{l}\text { Variety } \\
\text { (factor } \\
\text { A) }\end{array}$ & $\begin{array}{l}\text { Treatment } \\
\text { option } \\
\text { (factor B) }\end{array}$ & $\begin{array}{l}\text { Yield, } \\
\text { t/ha }\end{array}$ & $\begin{array}{l}\text { Increas } \\
\text { e to } \\
\text { control, } \\
\text { t/ha }\end{array}$ & $\begin{array}{l}\text { Grain } \\
\text { mass } \\
1000, \mathrm{~g}\end{array}$ \\
\hline \multirow{5}{*}{$\begin{array}{l}\text { Annus } \\
\text { hka }\end{array}$} & Control & 0.92 & & 110.2 \\
\hline & $\begin{array}{l}\text { Grade } \\
(\mathrm{Cu})\end{array}$ & 1.64 & 0.72 & 151.2 \\
\hline & $\begin{array}{l}\text { Grade } \quad \text { B } \\
(\mathrm{Zn})\end{array}$ & 1.28 & 0.36 & $122.6^{*}$ \\
\hline & $\begin{array}{ll}\text { Grade } & \mathrm{D} \\
(\mathrm{Mn}) & \end{array}$ & 1.44 & 0.52 & $120.1^{*}$ \\
\hline & $\begin{array}{ll}\text { Grade } & \mathrm{E} \\
(\mathrm{Fe}) & \end{array}$ & 1.40 & 0.48 & 140.2 \\
\hline \multirow{5}{*}{$\begin{array}{l}\text { Milyau } \\
\text { sha }\end{array}$} & Control & 0.62 & & 98.9 \\
\hline & $\begin{array}{l}\text { Grade } \quad \text { A } \\
(\mathrm{Cu})\end{array}$ & 1.28 & 0.66 & $99.8^{*}$ \\
\hline & $\begin{array}{l}\text { Grade } \quad \text { B } \\
(\mathrm{Zn})\end{array}$ & 1.04 & 0.42 & $99.9 *$ \\
\hline & $\begin{array}{ll}\text { Grade } & \text { D } \\
(\mathrm{Mn}) & \end{array}$ & 1.41 & 0.79 & 113.7 \\
\hline & $\begin{array}{l}\text { Grade E } \\
(\mathrm{Fe})\end{array}$ & 0.82 & 0.20 & $100.5^{*}$ \\
\hline \multicolumn{2}{|c|}{ LSD for $A \quad P \leq 0.05$} & 0.36 & & \\
\hline \multicolumn{2}{|c|}{ LSD for B $\mathrm{P} \leq 0.05$} & 0.24 & & \\
\hline
\end{tabular}

Table 3. Content of dry matter and macroelements in soybean grain, \%, 2018

\begin{tabular}{|c|c|c|c|c|}
\hline Option & $\begin{array}{l}\text { Dry } \\
\text { matter, } \\
\%\end{array}$ & Nitrogen & $\begin{array}{l}\text { Phosphoru } \\
\text { s }\end{array}$ & $\begin{array}{l}\text { Potassiu } \\
\mathrm{m}\end{array}$ \\
\hline \multicolumn{5}{|c|}{ Annushka } \\
\hline Control & 85.5 & 3.74 & 0.76 & 2.84 \\
\hline $\begin{array}{l}\text { Grade A } \\
(\mathrm{Cu})\end{array}$ & $89.9 *$ & $3.47 *$ & $0.87 *$ & $3.19 *$ \\
\hline $\begin{array}{l}\text { Grade B } \\
(\mathrm{Zn})\end{array}$ & $90.2 *$ & $3.46^{*}$ & $0.86^{*}$ & $2.99 *$ \\
\hline $\begin{array}{l}\text { Grade D } \\
(\mathrm{Mn})\end{array}$ & $85.7 *$ & $3.55^{*}$ & 0.91 & $2.99 *$ \\
\hline $\begin{array}{l}\text { Grade E } \\
(\mathrm{Fe})\end{array}$ & $91.0 *$ & $3.51 *$ & 1.03 & 3.23 \\
\hline \multicolumn{5}{|c|}{ Milyausha } \\
\hline Control & 90.1 & 3.88 & 0.81 & 2.90 \\
\hline $\begin{array}{l}\text { Grade A } \\
(\mathrm{Cu})\end{array}$ & $91.4 *$ & $3.88 *$ & $0.91 *$ & $3.03 *$ \\
\hline $\begin{array}{l}\text { Grade B } \\
\text { (Zn) }\end{array}$ & $91.4 *$ & $3.89 *$ & $0.81 *$ & $2.94 *$ \\
\hline $\begin{array}{l}\text { Grade D } \\
(\mathrm{Mn})\end{array}$ & $90.6 *$ & $3.75^{*}$ & 1.26 & 3.62 \\
\hline $\begin{array}{l}\text { Grade E } \\
(\mathrm{Fe})\end{array}$ & $91.3 *$ & $3.99 *$ & 0.93 & $2.83 *$ \\
\hline
\end{tabular}

Note: ${ }^{*}$ - the difference is not reliable in relation to the control for the corresponding class in terms of the standard deviation at $\mathrm{P}=0.05$ (5\% error)
For Annushka variety, the maximum yield was obtained through foliage feeding with $\mathrm{A}(\mathrm{Cu})$ fertilizer (yield increase by $0.72 \mathrm{t} / \mathrm{ha}$ ).

For Milyausha variety, the highest soybean yield was when plants were treated with a preparation containing manganese (yield increase by $0.79 \mathrm{t} / \mathrm{ha}$ ). The yield was slightly lower $(0.66 \mathrm{t} / \mathrm{ha})$ when copper preparation was used.

Annushka variety demonstrated a reliable increase in the weight of seeds feeding caused by the application of the preparation with copper, and Milyausha - with manganese.

The use of fertilizer feeding affected the content of macroelements and dry matter in soybean grains.

Foliage feeding had little effect on dry matter and total nitrogen in soybean grains. However, the use of manganese and iron-based fertilizers in both varieties increased the accumulation of phosphorus in the grain.

For Annushka variety, the growth of potassium content in the grain was noted in the option with iron, and for Milyausha variety - when sprayed with the preparation with manganese.

In order to determine the effect of foliage feeding on total removal of mineral feed elements with grain harvest, the corresponding calculations were carried out (Table 4).

Table 4. Removal of macroelements with grain harvest in various soybean varieties using foliage application of microelements, $\mathrm{kg} / \mathrm{ha}, 2018$

\begin{tabular}{|c|l|l|l|l|}
\hline $\begin{array}{c}\text { Variety } \\
\text { (factor } \\
\text { A) }\end{array}$ & $\begin{array}{c}\text { Treatment } \\
\text { option (factor } \\
\text { B) }\end{array}$ & $\begin{array}{c}\text { Nitro } \\
\text { gen }\end{array}$ & $\begin{array}{c}\text { Phosph } \\
\text { orus }\end{array}$ & $\begin{array}{c}\text { Potas } \\
\text { sium }\end{array}$ \\
\hline \multirow{4}{*}{$\begin{array}{c}\text { Annush } \\
\text { ka }\end{array}$} & Control & 29.4 & 6.0 & 22.3 \\
\cline { 2 - 5 } & Grade A (Cu) & 51.2 & 12.8 & 47.0 \\
\cline { 2 - 5 } & Grade B (Zn) & 39.9 & 9.9 & 34.5 \\
\cline { 2 - 5 } & Grade D (Mn) & 43.8 & 11.2 & 36.9 \\
\cline { 2 - 5 } & Grade E (Fe) & 44.7 & 13.1 & 41.2 \\
\hline \multirow{4}{*}{$\begin{array}{c}\text { Milyau } \\
\text { sha }\end{array}$} & Control & 21.7 & 4.5 & 16.2 \\
\cline { 2 - 5 } & Grade A (Cu) & 45.4 & 10.6 & 35.4 \\
\cline { 2 - 5 } & Grade B (Zn) & 37.0 & 7.7 & 27.9 \\
\cline { 2 - 5 } & Grade D (Mn) & 47.9 & 16.1 & 46.2 \\
\cline { 2 - 5 } & $\begin{array}{l}\text { Grade E } \\
\text { (Fe) }\end{array}$ & 29.9 & 7.0 & 21.2 \\
\hline \multirow{2}{*}{} & & & \\
\hline
\end{tabular}

The results of assessment showed that Annushka variety had higher NPK removal with grain yield than Milyausha variety. The use of all treatment options led to the increase of macroelements removal, primarily due to the increase of the soybean yield. In both soybean varieties, the maximum nitrogen removal was obtained by feeding with preparations containing copper and zinc. The largest consumption of phosphorus in Annushka variety was with the use of preparations with iron and copper, and in Milyausha variety - with manganese. For potassium the option with copper was marked for the first variety, and with manganese - for the second.

A study of protein content showed that the use of foliage fertilizers containing copper and zinc has a positive effect on the increase of protein accumulation in 
the grain in both soybean varieties, which is essential given the role of the culture as a source of the given nutrients for humans and animals [8].

\section{Conclusion}

The studies showed that the response of soybean to foliage fertilizers in the budding-early bloom stage depends on the variety and nutrient elements contained in a fertilizer.

All preparations stimulated the growth of plants, but regardless of the variety, the most pronounced effect was for the preparation with manganese. A number of researchers also indicates high importance of manganese for soybean harvest $[25,26]$. The formation of the number of beans and the number of grains in them within different varieties during feeding with different microelements was different.

While for Polish variety Annuska the best results were obtained by using the preparation with copper, for the Russian class Milyausha the advantage was for microfertilizer with manganese.

The studies confirmed data obtained through some studies [27, 28] on high efficiency of foliage application of microfertilizers and the need to consider the grade characteristics of the culture. Apparently, spraying of plants with soy solutions of fertilizers with microelements and with biologically active substances activates metabolism thus increasing the consumption of nutrients and yield growth, as well as the quality characteristics of culture grain.

The obtained results allow using this technique in soybean harvest management technologies in the Middle Volga zone of Russia, including in the Republic of Tatarstan.

\section{Recommendations}

Foliage application of liquid fertilizers of Metallocene A $(\mathrm{Cu})$ and $\mathrm{D}(\mathrm{Mn})$ is possible to increase soybean yield.

\section{References}

1. D. Shpaar, Leguminous crops 272 (DLV AgroDelo, Moscow, 2014)

2. T. Sakai, M. Kogiso, Soyisoflavones and immunity J. of Medical Investigation 55, 167-173 (2008)

3. N. Ali, Soybean processing and utilization In G. Singh, Ed., The soybean 345-374 (CABI, 2010)

4. K. Liu, Food use of whole soybeans In L. Johnson, P. J. White, R. Galloway, Eds., Soybeans: chemistry, production, processing, and utilization 441-482 (AOCS Press, Urbana, IL, 2008)

5. S. Shanmugasundaram, M.-R. Yan, Vegetable soybean In G. Singh, Ed., The soybean 427-460 (CABI, 2010)

6. V.S. Petibskaya, Soybean: chemical composition and use (Maykop, 2012)
7. H. F. Zheng, L. D. Chen, X. Z. Han, The effects of global warming on soybean yields in a long-term fertilization experiment in Northeast China J. of Agricultural Science 147, 569-580 (2009)

8. V.A. Fedotov, Soybean in Russia (Agroliga of Russia, Moscow, 2013)

9. M.Kh. Avzalov, Scientific basis and practical techniques of soybean cultivation in the conditions of the South-East of the Republic of Tatarstan: extended abstract of dissertation 17 (Kazan State Agricultural Academy, Kazan, 2004)

10. R.M. Gainullin, Growing lupine and soybean in Tatarstan Achievement of Science and Technology of the Agro-Industrial Complex 9, 48 (2007)

11. A.N. Fadeeva, N.G. Kurchatkin, Kh.V. Gimatdinov, Peculiarities of soybean cultivation in Tatarstan Niwa of Tatarstan 2-3, 18-20 (2016)

12. M.P. Mordvintsev, Soybean varieties for Volga region and Southern Ural and technological techniques of their cultivation. Agrobiological features, cultivation technologies and parameters of models of highly productive agrocenosis of field crops in arid conditions of the Southern Ural: scientific works, anniversary issue 160-169 (Publishing Center of Orenburg State Agrarian University, Orenburg, 2006)

13. M.P. Mordvintsev, Modern varieties of soybean of Volga breeding and their cultivation in irrigated crop rotations of Orenburg region J. of meat cattle breeding 1(89), 104-108 (2015)

14. L.M. Onishchenko, Fertilizers and productivity of soybean 317-324 (2005)

15. S.K. Singh, V.R. Reddy, H.D. Fleisher, J.D. Timlin, Growth, nutrient dynamics, and efficiency responses to carbon dioxide and phosphorus nutrition in soybean J. Plant Int. 9, 838-849 (2014)

16. S.V. Spitsyna, A.A. Tomarovsky, G.V. Ostvald, M.V. Tretiakov, Efficiency of micronutrients for soybean J. of the Altay State Agrarian University 8, 43-47 (2015)

17. M.F. Inocêncio, Á.V. De Resende, A.E.F. Neto, M.P. Veloso, F.M. Ferraz, C. Hickmann, Soybean response to zinc fertilization in soil with contents above critical level Pesquisa Agropecuária Brasileira 47(10), 1550-1554 (2012)

18. N.M. Tishkov, Productivity of soybean in case of foliage feeding of plants by micro-removal and treatment by growth regulators on leached chernozem Oilseeds. VNIIMK 2(137), 91-97 (2007)

19. J.T. Enderson, A.P. Mallarino, M.U. Haq, Soybean yield response to foliar-applied micronutrients and relationships among soil and tissue tests Agron. J. 107, 2143-2161 (2015)

20. P.I. Anspock, Micronutrients 272 (Agropromizdat, Leningrad, 1990)

21. P. Calvo, L. Nelson, J.W. Kloepper, Agricultural uses of plant biostimulants Plant Soil 383, 3-41 (2014) 
22. M. Popko, I. Michala, R.Wilk, H. Górecki, Effect of the New Plant Growth Biostimulants Based on Amino Acids on Yield and Grain Quality of Winter Wheat Molecules 23, 470 (2018)

23. A. Kahraman, Nutritional value and foliar fertilization in soybean J. Elem. 22(1), 55-66 (2017)

24. B.A. Dospekhov, Field experience methodology (Agropromizdat, Moscow, 1985)

25. B. Gordon, Manganese nutrition of glyphosateresistant and conventional soybeans Better Crops 91/4, 12-13 (2007)
26. A.E. Baxter, R.O. Maguire, G. Whitehurst, D. Holshouser, M. Reiter, Novel Fertilizer as an Alternative for Supplying Manganese and Boron to Soybeans Communications in Soil Science and Plant Analysis 50(1), 65-76 (2019)

27. N.M. Tishkov, A.A. Dryakhlov, Efficiency of soybean foliage application with micronutrients on leached chernoxem of Western Pre-Caucasis Scientific and technical bulletin of the All-Russian Research Institute of Oilseeds 1, 157-158 (2014)

28. V.P. Derevyansky, M.V. Stryuk, Influence of microelements on soybean productivity Technical cultures 4, 8-9 (1993) 